ISSN: 2146-3042

DOI: $10.25095 /$ mufad.536033

\title{
İç Denetim Sisteminin Hileli Finansal Raporlamayı Önlemedeki Rolüne Yönelik Bağımsız Denetçiler Üzerinde Bir Araştırma*
}

\author{
Mehmet DEMIR** \\ M. Mustafa KISAKÜREK ${ }^{* * *}$ \\ Öznur ARSLAN ${ }^{* * * *}$
}

\section{ÖZET}

Bu çalışmada, hileli finansal işlemlerin tespit edilme sıklıklarının düzeyini ve iç denetim sisteminin hileli finansal raporlamayı önlemedeki rolünü tespit etmek amaç olarak belirlenmiştir. Bu amaçları gerçekleştirmek için Türkiye'de faaliyet gösteren bağımsız denetim şirketlerinde çalışan, 300 bağımsız denetçiye 2017 HaziranĂgustos döneminde bir anket uygulanmıştır. Anket verileri SPSS 22 paket programindan yararlanılarak analiz edilmiştir. Araştırmanın Cronbach's Alpha güvenirlik katsayısı 0,84'tür. Elde edilen verilerin analizi sonucunda iç denetim sisteminin hileli finansal raporlamayı önlemedeki rolüne ilişkin ifadelerden "iç denetçinin denetim standartlarını bilmemesi hileli finansal raporlama yapılma riskini artırı" ifadesinin daha çok benimsendiği tespit edilmiştir.

Anahtar Kelimeler: Bă̆ımsız Denetçi, İç Denetim, Denetçi, Hile, Hileli Finansal Raporlama.

JEL Sınıflandırması: M41, M42.

\section{The Role Of The Internal Audit System In The Preventive Of Fraudulent Financial} Reporting A Research On Independent Auditors

\section{ABSTRACT}

The purpose of this study was to determine the level of frequency of detection of fraudulent financial transactions and to determine the role of the internal audit system in preventing fraudulent financial reporting. To accomplish these objectives, was carried a survey to over 300 independent auditor employees in independent audit firms in Turkey during the period June-August 2017. Survey data were analyzed using SPSS 22 package program. The Cronbach's Alpha reliability coefficient of the study is 0,84. As a result of the analysis, from statements regarding the role of the prevention of fraudulent financial reporting of internal audit system "The fact that the internal auditor does not know the audit standards increases the risk of fraudulent financial reporting" it has been found more than other phrase.

Keywords: Independent Auditors, internal audit, Auditor, Fraud, fraudulent financial reporting.

Jel Classification: M41, M42.

Makale Gönderim Tarihi: 30.07.2018

Makale Kabul Tarihi: 03.10.2018

\footnotetext{
${ }^{*}$ Bu çalışma, Cumhuriyet Ü. SBE, İşletme ABD doktora tezi kapsamında Doç. Dr. Mehmet DEMİ'in danışmanlığında Öznur Arslan'ın hazırlamış olduğu “Muhasebe Hilelerinin Tespitinde İç Denetim Sisteminin Önemi ve Denetim Standartları Açısından Bağımsız Denetçinin Hileye Karşı Sorumlulukları” adlı doktora tezinin özellikle anket formu, evren ve örnekleminden yararlanmak suretiyle gerçekleştirilmiştir.

** Doç. Dr., Cumhuriyet Üniversitesi, İktisadi ve İdari Bilimler Fakültesi, mehmet_demir01@ @otmail.com, ORCID ID: 0000-0003-1796-7974

*** Doç. Dr., Kahramanmaraş Sütçüimam Üniversitesi ,İktisadi ve İdari Bilimler Fakültesi, mmk_46@hotmail.com, ORCID ID: 0000-0003-2351-4314

**** Öğr. Gör. Dr., Cumhuriyet Üniversitesi, Hafik Meslek Yüksek Okulu, oznurarslannn@ gmail.com, ORCID ID: 0000-0001-5973-9107
} 


\section{GíRiş}

Muhasebe bilgi sistemi içinde üretilen finansal tablolar, şirketlerin finansal yapısı, faaliyet sonuçları ve bunlardaki süregelen gelişim hakkında bilgi sahibi olmayı sağlayan en önemli araçlardan biridir. Ancak finansal tabloların üretilmesine imkân sağlayan muhasebe bilgi sisteminin, işletme yetkilileri veya denetçiler tarafindan muhasebe standartlarının oluşturduğu boşluklar ya da yasal düzenlemelere aykırı uygulamalar yoluyla manipüle edildiği görülmektedir.

Finansal bilgi manipülasyonları içerisinde değerlendirilen uygulamaların bazılarında muhasebe ilkelerinden ve standartlarından açık biçimde sapmaların olduğu gözlenmektedir. Bu tür "muhasebe ilke ve standartlarına aykırı manipülasyonlar" aynı zamanda "finansal hile" olarak adlandırılmaktadır (Tepeli ve Kayıhan, 2016:248).

Finansal hile olgusu beraberinde hileli finansal raporlamayı getirmektedir. Hileli finansal raporlama sebebiyle, şirketlerin gerçek finansal durumları ve faaliyet sonuçları gizlenmekte bu durum ise yatırımcıların zarara uğramasına, sisteme olan güvenin sarsılmasına, kaynakların yanlış ve verimsiz alanlara tahsis edilmesine yol açmaktadır (Küçükkocaoğlu ve Küçüksözen, 2004:161). Sertifikalı Hile Araştırmalar Kuruluşu (Association of Certified Fraud Examiners -ACFE) tarafindan yayinlanan 2016 Hile Raporu'nda işletmelerin varlıklarının ortalama \%5' ini hileli işlemlerden dolayı kaybettiği ve hileli finansal raporlama sebebiyle oluşan kayıpların her yıl ortalama 3,7 trilyon dolardan fazla olduğu belirtilmektedir. Bu olumsuz etkilerin önlenmesi ya da ortadan kaldırılması amacıyla gerek uluslararası gerekse ulusal alanda birçok yasal düzenleme yapılmıştır.

\section{HILE VE HATA KAVRAMLARI}

Özellikle 2000'li yıllarda finansal bilgilerin gerçeği yansıtmaması ile ortaya çıkan finansal skandallar "hile" kavramının üzerinde daha çok durulmasına yol açmıştır.

Kasıt taşımayan ve hata olarak adlandırılan davranışlardan ayrılan hile, bu yönüyle bilinçli olarak yapılan bir fiil olarak tanımlanmaktadır. Hile, eylemi gerçekleştirenin, kendi menfaati lehinde aldatma yoluyla kıymeti olan bir şeyi elde etmesi veya bir yükümlülükten kaçınması şeklinde tanımlanabilir. Buradan hareketle hile en genel tanımıyla kasıtlı aldatma olarak ifade edilebilir (Hacıhasanoğlu ve Karaca 2015: 118).

Muhasebe açısından literatürde hileyle ilgili çok çeşitli tanımlar yer almaktadır. Bunlardan bazılarına aşağıda yer verilmiştir.

Hile, parayla ifade edilen olayların oluşumu, belgelenmesi, kaydedilmesi ve işletme ile ilgili çıkar çevrelerine rapor edilmesi aşamasında kötü niyetle, ilgili çıkar çevrelerinin bilgisi dışında ve onları maddi zarara uğratacak şekilde basılı ve dijital ortamda ulusal ve uluslararası mevzuata aykırı davranmak, davranmaya teşvik etmek veya böyle bir ortamda suça iştirak etmektir (Bayraklı ve diğerleri 2012: 51).

SAS (Statement of Auiditing Standards) 82 No.lu Denetim Standartlarına İlişkin Açıklama'da hile; bilinçli bir şekilde, finansal tabloların raporlanmasında veya finansal tablolarda yer alan varlıkların üzerine bilgi ve belge saklanması ya da ilave edilmesi olarak tanımlanmıştır. 
ACFE'nin tanımına göre hile, başkalarını aldatarak kazanç elde edilmesi veya çalışanlar tarafından işletme varlık ve kaynaklarının zimmete geçirilmesidir.

Vergi Usul Kanunu (VUK)'nda hilenin tanımı yapılmamış fakat VUK'un Kaçakçılık ve Suçları ve Cezaları'nı düzenleyen 359'uncu maddesinde hangi uygulamaların suç sayıldığ 1 maddeler halinde sıralanmıştır.

Sermaye Piyasası Kurulu (SPK)'nun Seri: X, No: 22 tebliğinde hile, işletme yönetiminin, işletme çalışanlarının veya üçüncü şahısların bilerek ve isteyerek yasal olmayan bir yarar sağlamak gayesiyle aldatma içeren davranışlarda bulunmaları olarak tanımlanmaktadır.

Muhasebede hata ise, mali tablolardaki kasıt olmayan yanlışlıklardır. Bunlar, kaydedilmesi gereken bir ekonomik olayın, bir tutarın veya bir açıklamanın mali tablolarda yer verilmemesi neticesinde ortaya çıkarlar. Hatalar, bir kıymet hareketinin defterlere kaydedilmemiş olması, bir kıymet hareketinin ait olduğu döneme değil, bir başka muhasebe dönemine kaydedilmiş olması, yanlış bir tutar ile kaydedilmiş olması ya da yanlış bir hesaba borç veya alacak kaydedilmiş olması sonucu ortaya çıkar (Şengür 2010: 6).

Hatalarda bilgisizlik, dikkatsizlik ve ihmal vardır. Kasıt yoktur. Hile ise haksız kazanç elde etmeyi amaçlayan bir davranıştır. Hile yapan kişilerin amacı, kendi hakları olamadığ halde bir çıkar gözetmesi ve elde etmesidir. Diğer bir ifadeyle hata yapanlar kendi menfaatlerini gözetmezler ama davranışları başkalarına zarar verir; ancak hile yapanlar hem kendi çıkarlarını düşünürler hem de başkalarına zarar verirler (Dumanoğlu 2005: 349).

\section{I. Hile Üçgeni}

Donald R. Cressey tarafindan 1940'ların sonlarında geliştirilen teoriye göre; hileden söz edilmesi için baskı, fırsat ve haklı gösterme olarak adlandırılan üç durumdan en az birinin var olması gerekir. Hile risk faktörlerinin altında yatan teoriyi oluşturan hile üçgeni olarak da bilinen bu yaklaşım, SAS No: 99'da Cressey'in teorisine göre ele alınmış ve bir hilede, hile üçgenindeki üç durumun da var olduğu belirtilmiştir. Hilenin gerçekleştiği ortamlarda genellikle bu üç durumun var olduğu ileri sürülmekle birlikte, hile potansiyelinin oluşabilmesi için hile üçgenindeki tek bir unsurun varlığı da yeterli görülmüştür. (AICPA, SAS No:99; Paragraf 7; Küçük ve Uzay 2009: 243; Skousen 2004: 7; Wolfe ve Hermanson 2004: 38, Uçma 2010: 28)

\section{I. I. Baskı}

Hileli finansal raporlama yapılmasını gerektirecek baskılar, işletmede ya da işletmenin yer aldığı sektörde yaşadığı ani hasılat düşüşleri ya da pazar payı daralmasından kaynaklanabilir. İşletmenin mevcut durumu dikkate alınmadan yapılan bütçeler, işletme ile ilgili gerçek dışı beklentiler doğurmaktadır. Gerçek dışı beklentiler ise özellikle kısa dönemde işletme yönetimleri üzerinde baskı oluşturarak, hileli finansal raporlama yapılmasına yöneltebilecek önemli bir unsur olarak karşımıza çıkmaktadır. İşletmelerin kısa dönemdeki performansları "prim" ile ödüllendiriyor olması da kişiler üzerinde ciddi bir bask1 oluşturmaktadır. Kısa dönemdeki performansa bağlı olarak elde edilecek olan primin, kişinin toplam kazancı içerisindeki oranı arttıç̧a, kişi üzerinde doğuracağı baskı da o oranda artacaktır. $\mathrm{Bu}$ durum kişiyi gerçekte elde edemediği performansı, elde etmiş gibi gösterebilmek için hileli finansal raporlama yapmaya itecektir. Otokratik bir üst yönetim bulunması ve bu yönetimin performansın yüksek olmasına yönelik yaptığı baskılar sonucunda 
hileli finansal raporlama söz konusu olabilir. Sermaye piyasalarından kaynaklanan baskılar ve yöneticilerin sermayelerini düşük bir maliyet ile arttırma çabaları da manipülasyon yapılmasina ve hileli finansal raporlamaya sebep olabilmektedir (Tarhan Mengi 2013: 17).

\section{1. 2. Fursat}

İşletmelerde iç kontrol sisteminde bir eksiklik veya zayıflık, hile yapmak için firsat doğurmaktadır. Baskı unsuru, firsatla birleştiğinde hile yapılma olasılığı da çok yükselecektir. Bir işletmede hile yapılmasını tetikleyen firsat unsurları şöyle sıralanabilir (Terzi 2012: 38).

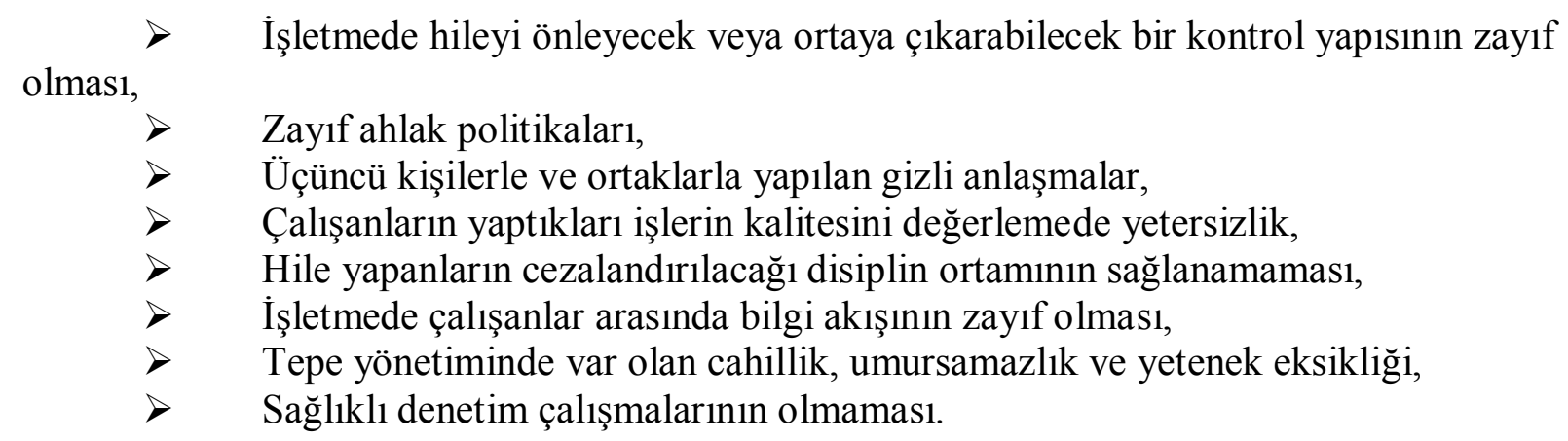

\subsubsection{Haklı Gösterme}

Hile üçgeninin üçüncü faktörü ise davranış1 rasyonelleştirme veya haklı göstermedir. Hile yapan kişiler suç davranışına girdiklerinde kendilerini haklı göstermeye çalışmaktadır. Yaptıkları hileyi doğru göstermek için de kendilerini ikna etme çabasıyla bahaneler üretmektedirler. Hile yapan kişilerin bahane olarak sıralayabileceği cümlelerden bazıları şu şekilde sıralanabilir (Çıtak 2013: 20).

\begin{tabular}{|l|l|}
\hline Bu olay sonucu hiç kimseyi incinmedi. & Yaptı̆̆ımın suç olduğunu bilmiyordum. \\
\hline Bu işletmeye yaptıklarımın karşıllı̆̆ıdır. & Parayı sadece borç almıştım, geri ödeyeceğim. \\
\hline Bu parayı iyi bir amaç için almıştım. & Onlar bana ait, daha fazlasını hak ettim. \\
\hline Onu hak ettim. & Ne yapttyssam işletme için yaptım. \\
\hline Herkes yapar kimseye zarar vermedim. & İşletme bunu hak etmişti. \\
\hline Sadece bir kerelik ihtiyacım vardl. & Sadece kendi payımı istiyorum. \\
\hline
\end{tabular}

Ayrıca; ekonomik istikrarsızlık, geleceğe yönelik belirsizlikler ve bunları telafi etmeye dönük olarak kullanılan sosyal adalet sisteminin yetersizliği, vergi ödeyebilecek güçte olmalarına rağmen kişileri ödemesi gereken vergiyi bir kaynak olarak düşünmeye ve bu kaynağı ileride ortaya çıkabilecek sıkıntılı dönemlerde kullanmak üzere ihtiyat akçesi olarak ayırmaya itebilmektedir. 
Aşırı baskının olduğu ortamlarda, kendisinden hileli davranış beklenmeyen kişiler bile yanlış ve yanıltıcı bir şekilde davranabilir. Bir kişinin hileye bulaşma hareketini meşrulaştırma eylemi teşvik ve baskının büyüklüğü ile doğru orantılıdır (Uçma 2010: 29).

\subsection{Hile Karosu}

Acaba baskı altında olan her kişi, kendini haklı göstererek hile yapabilir mi; karşısında bir firsat mevcut olsa dahi herkes bu firsatı fark edebilir mi; bu firsatı değerlendirebilir mi? Mevcut firsatları fark edebilmek, değerlendirebilmek ve hile eylemini gerçekleştirebilmek için kişilerin bazı yetkinliklerinin de olması gereklidir (Tarhan Mengi 2013: 119). Dolayısıyla hile üçgeni yaklaşımına ek olarak Wolfe ve Hermenson, kişinin hile yapmadaki yeteneğini, diğer bir ifade ile hileyi gerçekleştirebilmeye yetebilecek bilgi ve beceriye sahip olması özelliğini dördüncü bir unsur olarak hile üçgenine eklemiştir. Kişileri hile yapmaya iten unsurların değerlendirilmesinde yetkinliklerin dikkate alınması hile üçgenini, hile karosuna dönüştürmüştür (Doğan ve Kayakıran 2017: 173).

\section{HILLE TÜRLERI}

ACFE tarafından yayınlanan raporda hile türleri aşağıdaki şekilde sınıflandırılmıştır. Bu sınıflandırmaya hile ağacı ismi de verilmektedir. ACFE hile ağacında üç temel hile çeşidi yer almaktadır. Bu üç temel hile çeşidi Şekil 1 de gösterilmiştir.

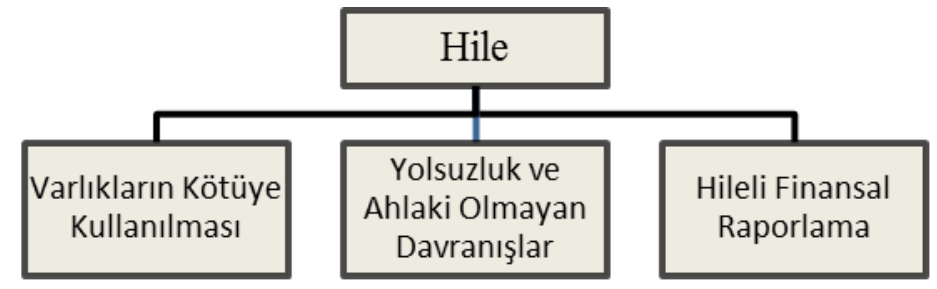

Şekil 1. Hile Çeşitleri

Kaynak: ACFE, 2006 Report To The Nation Occupational Fraud\&Abuse

Şekil 1'de görüldüğü gibi, varlıkların kötüye kullanılması, yolsuzluk ve ahlaki olmayan davranışlar ve hileli finansal raporlama hile ağacındaki hile çeşitlerini oluşturmaktadır.

Varlıkların kötüye kullanılması; varlıkların çalınması ya da amaç dışı kullanılmasıdır. Varlıkların kötüye kullanımı genellikle işletme çalışanlarının işletmeye ait varlıkları çalması şeklinde gerçekleştirilir ve genelde küçük tutardadır. Varlıkların kötüye kullanımı işletme yönetimi tarafindan nadir olsa da gerçekleştirilebilir. Ancak yönetimin yetki gücünün geniş olması, kontrolleri rahatlıkla yönlendirebilmesi gibi sebeplerle zimmete geçirilen kıymetler çok önemli tutarlara ulaşabilir (Güredin 2010: 134-135). İşletme personelinin ve diğer işletmelerdeki personelin, işletme varlıklarının haksız olarak elde edilmesine yardımcı olmaları da varlıkların kötüye kullanılması olarak adlandırılmaktadır.

Yolsuzluk ve ahlaki olmayan davranışlar; çalışanın işletme faaliyetlerinde işverenin ya da bir başkasının haklarını göz ardı ederek, gücünü yanlış bir biçimde kendisine veya başkasına yarar sağlama amaçlı kullanmasıdır. Bu gruba giren eylemler işletmenin zarar 
etmesine yol açmakta, yatırımcının güveni zedelenmekte, büyümeyi durdurmakta, kaynak dağılımının bozulmasına sebep olmakta ve işletmenin iflas riskini artırmaktadır (Özeroğlu 2014: 185)

Hileli finansal raporlama; finansal tablo kullanıcilarını aldatmak amaciyla kasitlı bir şekilde finansal tablolarda yer alması gereken tutarların yer almaması ve/veya olmaması gereken tutarların finansal tablolarda yer alması şeklinde gerçekleşmektedir. Bunlar genellikle üst yönetim tarafindan tamamen finansal tablo kullanıcıları aldatmak için yapılmaktadır. Amerikan Sertifikalı Kamu Denetçiler Enstitüsü (American Institute of Certified Public Accountants- AICPA)'nün hile ile ilgili yayınladığı standart SASNo.99'un altınc1 paragrafinda hileli finansal raporlama teknikleri sıralanmıştır

> Finansal tabloların oluşmasına yardımcı olan önemli belgelerin yok edilmesi, tahrif edilmesi veya önemli kayıtların çarpıtılması

$>\quad$ Finansal işlem, olay ve diğer önemli bilgilerin, finansal tablolarda önemli tahrifata yol açacak şekilde yanlış yansıtılması veya hiç yansıtılmaması

> Muhasebe ilkeleri, kayda alma, sınıflandırma, sunum ya da açıklama ile ilgili prosedürlerin kasıtlı olarak yanlış uygulanması.

Hileli finansal tablolar, yüksek meblağlarda zararlara sebep olabilmektedir. Hileli işlemlerin gerçekleştirilme süreci sadece bir kişi tarafından değil birçok kişi tarafından yapılmaktadır. Diğer hile yöntemlerine göre daha fazla sayıda toplumsal kesimi etkilemektedir (Coenen 2008: 96-97).

Bağımsız denetçiler, varlıkların zimmete geçirilmesinden ziyade hileli finansal raporlamayla daha çok ilgilenmektedirler. Çünkü hileli finansal raporlama finansal tablo kullanıcılarını aldatma amacı güderken, varlıkların zimmete geçirilmesi finansal tablolarda önemli zararlara sebep olsa da amaç finansal tablo kullanıcılarını yanıltmak değildir. Diğer taraftan hileli finansal raporlamanın maliyeti varlıkların zimmete geçirilmesine göre daha ağırdır (Varıc1 2012: 127).

ACFE tarafindan yapılan çalışmalar ve bu çalışmalar sonucunda yayınlanan raporlar hileli finansal raporlamanın sıklığı ve maliyeti hakkında önemli bilgiler sunmaktadır. İlgili kuruluş tarafindan yayınlanan raporlara göre yıllar itibariyle hileli finansal raporlamanın sıklığı, varlıkların kötüye kullanımı, yolsuzluk ve ahlaki olmayan davranışlar ile karşılaştırılmalı olarak Şekil 2'de gösterilmiştir. 


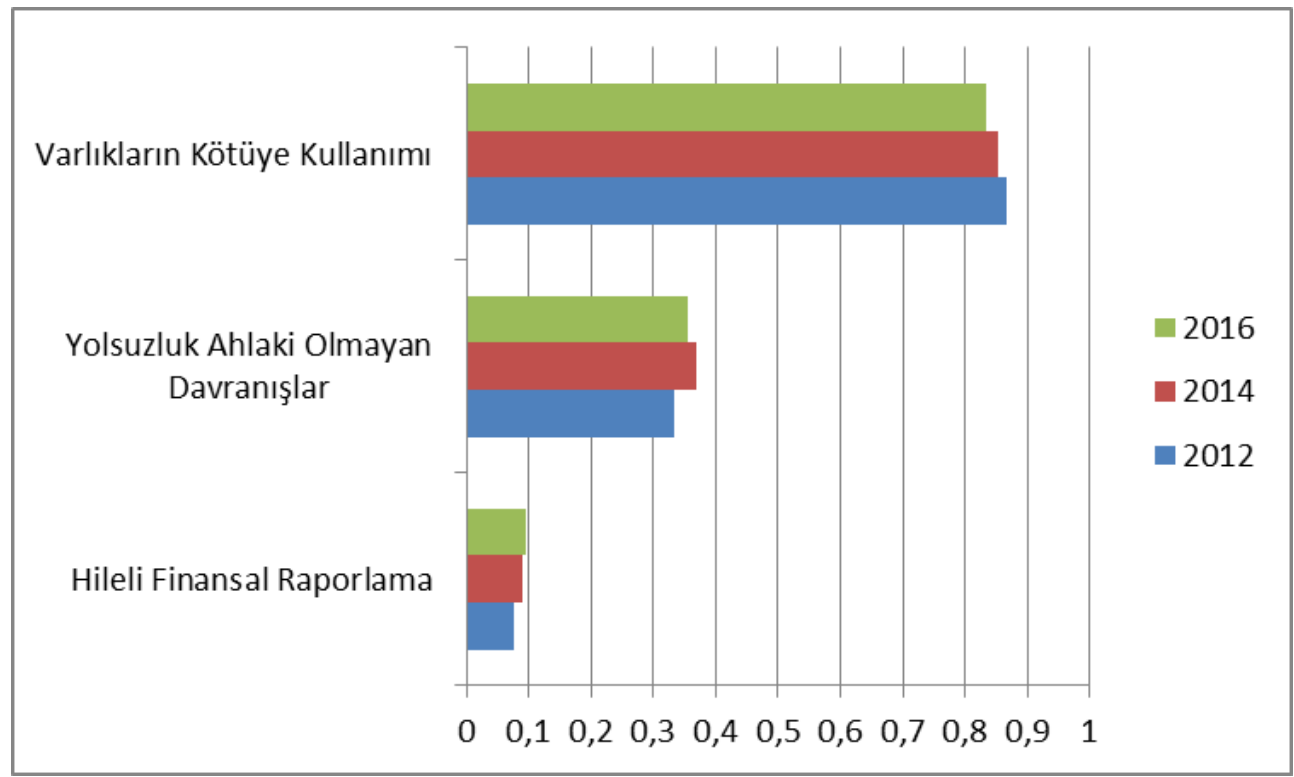

Şekil 2. Hileli Finansal Raporlama Sıklığının (\%) İşletme İçi Diğer Hile Türlerinin Sıklığı (\%) ile Karşılaştırılması

Kaynak: ACFE, 2016 Report To The Nation Occupational Fraud\&Abuse

Şekil 2 incelendiğinde işletme içerisinde en az sıklıkta ortaya çıkan hile türünün hileli finansal raporlama olduğu görülmektedir. Ancak bu açıdan yapılacak bir değerlendirme doğru sonuçlar veremeyebilir. Bu bağlamda işletme içi hilelerin verilen zararların tutarı açısından da bir değerlendirmeye tabi tutulması gerekmektedir. Bu değerlendirmenin sonucu Şekil 3 'te gösterilmektedir.

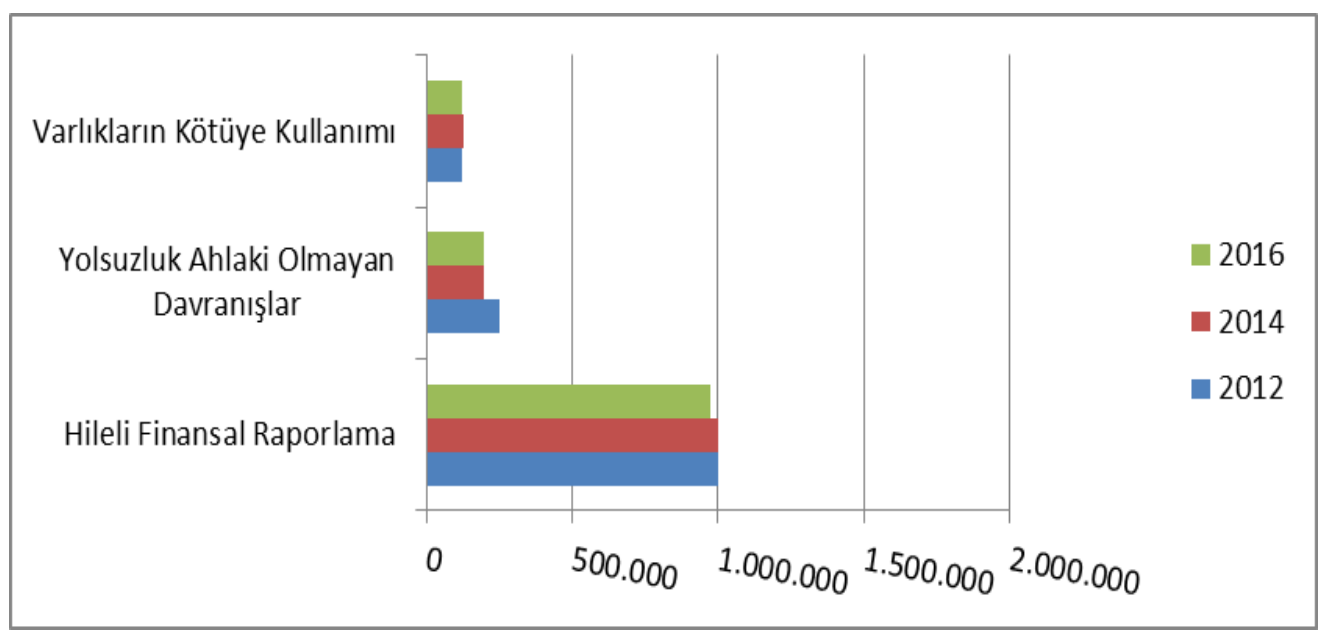

Şekil 3. Hileli Finansal Raporlamanın Verdiği Ortalama Zararların (\$) İşletme İçi Diğer Hile Türlerinin Verdiği Ortalama Zararlar (\$) ile Karşılaştırılması

Kaynak: ACFE, 2016 Report To The Nation Occupational Fraud\&Abuse

Şekil 3 incelendiğinde hileli finansal raporlama sıklığ 1 az olsa da yol açtığ 1 olduğu zararlar açısından işletme içi diğer hile türlerinin açık ara önünde yer aldığı görülmektedir. 


\section{HILLELI FINANSAL RAPORLAMANIN SEBEPLERİ}

Hileli finansal raporlama, genellikle kâr manipülasyonuna odaklanmaktadır. Bu durumun sebebi, şirketin piyasa değerinin belirlenmesinde kârın önemli bir rol oynamasıdır (Kandemir 2013: 43). İşletmelerin üst yönetimlerini hileli finansal raporlamaya iten başlıca sebepler şunlardır (Küçük 2009: 20);

Yaptıkları bu tür düzenlemelerden dolayı kendilerine yarar sağlamaları, örneğin işletme gelirlerinin artmasıyla prim elde etmeleri gibi,

$>\quad$ Yöneticilerin yönetim kademesinde olmasından dolayı muhasebe hilelerini yapmalarına uygun ortamı bulmaları,

$>\quad$ Yaptıkları hileli eylemler sonucunda yakalanmayacaklarını düşünmeleri, (zayıf iç kontrol yapıları ve denetim mekanizmasının varlığı gibi),

$>\quad$ Aşırı rekabetin varlığı ve bu rekabetten kaynaklı baskılarla karşılaşmaları,

> İşletme menkul kıymet piyasa değerinin yükselmesini sağlayarak yatırımcıların beklentilerini karşılamak,

\subsection{Hileli Raporlama Yöntemleri}

ACFE, hileli raporlama yöntemlerini genel olarak aşağıdaki Şekil 4'te görüldüğü gibi sinıflandırmaktadır.

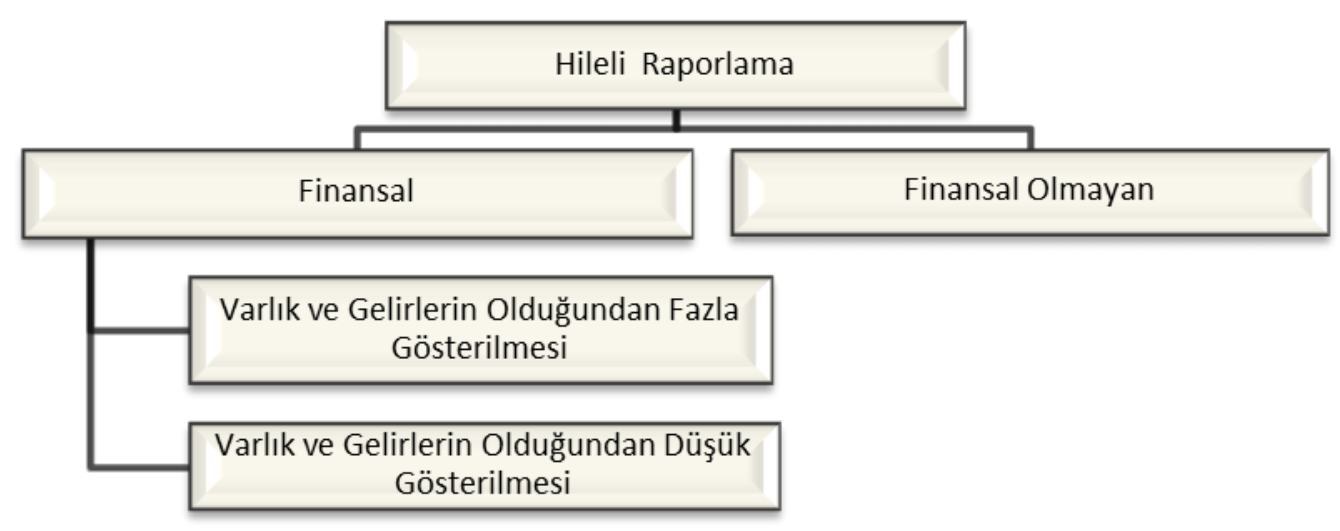

Şekil 4. Hileli Raporlama Yöntemleri

Kaynak: ACFE, 2008 Report To The Nation Occupational Fraud\&Abuse ayırmıştır.

Şekil 4'te hileli raporlama finansal ve finansal olmayan olmak üzere iki kategoriye

Finansal olmayan hileli raporlama, işletmenin finansal tablolarına etkisi olmayan rapor, evrak veya işlemler ile ilgili olarak kasti yanlışlıklar yapılması ve üçüncü kişilerin aldatılmasıdır. Finansal olmayan hileli raporlama; çalışanların özellikle mesleki sertifikalarla ilgili deneyimli olmaları durumu konusunda yanlış bilgiler sunulmasını, iç raporlama ve dış raporlama amacı ile ilgili olarak hazırlanmış rapor ve dokümanların kasıtlı olarak yanlış bilgileri içerecek şekilde hazırlanmasını içermektedir(Wallace 2008: 53). Finansal olmayan hileli raporlama literatürde çok yer almamaktadır. 
Finansal Hileli Raporlama, işletmenin finansal tablolarını etkileyen evrak kayıt ve finansal işlemleri ile ilgilidir. Finansal hileli raporlama türlerinden olan "Varlıkların/Gelirlerin olduğundan daha düşük gösterilmesi” teorik olarak imkân ve ihtimal dâhilinde olan, ancak uygulamada pek rastlanmayan hilelerdir ve genelde küçük işletmeler tarafindan yapılmaktadır. "Varlıkların ve Gelirlerin Olduğundan Daha Yüksek Gösterilmesi” hileleri ise dört alt kategoride incelenmektedir. Bunlar;

$>\quad$ Hayali Gelirler,

$>\quad$ Yükümlülük ve Giderler ile İlgili Hileli Finansal Raporlama,

$>\quad$ Varlıklara İlişkin Olarak Gerçekleştirilen Hileli Finansal Raporlama,

$>\quad$ Açılayıcı Notların Hiç Verilmemesi ya da Yeterli Düzeyde Olmaması

\section{5. İÇ DENETIMIN TANIMI}

İç denetim, bir kurumun idarecilerinin, sorumlu oldukları süreçlerin hile, hata veya verimli ve tutumlu olmayan uygulamaların meydana gelme olasılığını en aza indirecek şekilde işlediğine dair güvence elde etmesini sağlayan işlevsel bir araçtır. İç denetim, iç kontrol sisteminin etkinliğinin ölçülerek ve değerlendirilerek yönetime sunulan bağımsız bir belirleme hizmetidir (Akyel, 2010: 5).

İç denetim, işletme faaliyetlerinin ve bu faaliyetleri yürütenlerin yaptıkları işlemlerin önceden belirlenmiş hedeflere ve genel kabul görmüş muhasebe ilke ve standartları bütçe hedefleri gibi çeşitli kıstaslara uygunluğunun ve etkinliğinin araştırılarak yönetime raporlar sunulmasıdır (Durmuş ve Taş 2008: 11).

Uluslararası İç Denetçiler Enstitüsü (IIA), iç denetimi şu şekilde tanımlamaktadır. İç denetim, bir kurumun faaliyetlerini geliştirmek ve onlara değer katmak amacını güden, bağımsız ve objektif bir güvence ve danışmanlık faaliyetidir (Pickett, 2003: 239).

\section{I. İç Denetimin Amaçları ve Faydaları}

İç denetimin amaçları şu şekilde sıralanabilir (Uyar, 2009: 61):

Bir işletmede finansal olmayan kontroller de dâhil olmak üzere faaliyetlerin etkinliği, verimliliği ve yeterliliğinin sağlanması, işletme faaliyetlerinin sağlıklı ve verimli bir şekilde yürütülmesi,

İşlemlerin önceden saptanmış işletme politikasına uygunluğu ve doğruluğunun kontrol altında tutulması, işlemlerin amaçlara, programlara, stratejik planlara, performans programlarına ve mevzuata uygun olarak planlanması ve yürütülmesi,

$>\quad$ İşletme varlıklarının etkin ve verimli bir şekilde kullanılmasının sağlanması, varlıkların güvence altına alınması, sağlanması,

Bilgilerin güvenilirliğinin, bütünlüğünün ve zamanında elde edilebilirliğinin

Muhasebe ve iç kontrol sisteminin yeterlilik ve etkinliğinin incelenmesi, değerlendirilmesi, risklerin asgariye indirilmesi ve yönetilmesi,

Muhasebe sürecinin Genel Kabul Görmüş Muhasebe İlkeleri doğrultusunda devamının sağlanması, 


\author{
$>\quad$ Isşletmede meydana gelen veya gelebilecek olan hata ve hilelerin ortaya \\ çıkartılması ve önlenmesi, \\ $>\quad$ Varlıkların fiziki durumları ile defter kayıtları arasındaki ilişkinin kontrol \\ altında tutulmasi, \\ $>\quad$ Yönetime yardımcı olunması ve üst yönetime danışmalık yapılması, \\ $>\quad$ Belirli alanlarda özel araştırmaların yapılması, \\ $>\quad$ Denetim sonucunda maddi açıdan tasarruf sağlanması
}

İç denetimin faydaları aşağıda sıralanmaktadır. (Pehlivanlı 2010: 8).

Güvenilir bilgi ihtiyacının karşılanmasını sağlar: İç denetimin etkinliği iç kontrol sisteminin etkinliği ile direk bağlantılıdır. İşletmede etkin bir iç kontrol yapısı varsa iç denetimin etkinliği de yüksek olacaktır.

$>\quad$ İşletme varlık ve kayıtlarının korunması ihtiyacı karşılanır: Etkin bir iç denetim sisteminin var olması durumunda işletme varlık ve kayırlar da yüksek seviyede korunur.

$>$ Verimliliğin artması ihtiyacı karşılanır: İç denetimin etkin çalışması durumunda verimsiz faaliyetlerde azaltılabilecektir.

$>\quad$ Üst yönetim tarafından belirlenen politikalara uyum sağlanır.

\title{
5.2. İç Denetimi Gerektiren Sebepler
}

Küresel rekabet içinde sürekli büyüme ve gelişmeyi amaçlayan işletmeler, kurumsal yönetim kalitesini sağlamak için iç denetim faaliyetine ihtiyaç duymaktadırlar. Küçük ölçekli işletmelerde yöneticiler çalışanlarını ve işletmenin günlük faaliyetlerini takip edebilecek yeterliliktedir. İşletme büyüdükçe, işlemler karmaşıklaşmakta ve rekabet ortamında kurumun etkin yönetilmesi için iç kontrol ihtiyacı artmaktadır. İç kontrol sistemi ile birlikte, bağımsız ve tarafsız olarak yönetime güvence sağlayan, iç denetime olan ihtiyaç da artmaktadır. $\mathrm{Bu}$ ihtiyacı gören yönetim, işletmenin faaliyetlerini sermaye kaynaklarını ve risk faktörlerini dikkate alarak iç denetim uygulamalarının nasıl organize edileceğine karar verir (TUSİAD 2008: 6).

İç denetimi gerektiren sebepler sorumluluk ve hesap verme, yönetim danışmanlık ve yardım, hileli işlemlere karşı korunma ihtiyacı, vekâlet teorisi ve tasarruf ihtiyacı açılarından değerlendirilebilir.

\section{LITERATÜR İNCELEMESI}

Konu ile ilgili olarak daha önce yapılmış teorik ve ampirik çalışmalara ait özet bilgiler şöyledir.

Türedi ve Alıcı (2014) çalışmalarında, mali raporlama hilelerinin türleri, ne şekilde meydana geldikleri ve bunların sonuçlarına değinmişler; başarılı bir iç kontrol yapısının mali raporlama hilelerinin tespit edilmesi ve önlenmesindeki rolünü açıklamaya çalışmışlardır.

Atmaca (2012) çalışmasında, muhasebe skandalları ile işletmelerde ön plana çıkan iç kontrol sisteminin bu tür skandalları önlemede etkin bir araç olarak kullanılmasına yönelik teorik çerçevede açıklamalara yer vermiştir. 
Yıldız ve Başkan (2014) çalışmalarında, muhasebe hilelerinin önlenmesinde kullanılan araçları incelemişlerdir. Bunun için ise BIST'teki şirketler üzerinde bu araçların kullanılabilirliğini ve en etkili aracı tespit etmeyi amaçlamışlardır. Bu amaçla ulaşılan sonuca göre iç denetim, iç kontrol ve bağımsız denetimin finansal tablolarda görülen hileleri önlemede ilk üç sırada yer alan araçlar arasindadir.

Doğan ve Çıtak (2017) çalışmalarında, Borsa İstanbul'da faaliyet gösteren işletmelerde çalışan personelin, hileli finansal raporlamanın tespitinde ve önlenmesinde iç denetçinin sorumluluklarını belirlemeye yönelik oluşturulan yargılara katılma düzeylerini anket çalışmasıyla tespit etmişlerdir. Araştırma sonucunda iç denetçilerin, eğitimli ve mesleki yeterliliğe, tarafsılılı̆a ve yeterli muhasebe eğitimine sahip olmaları ayrıca iç denetim standartlarını ve risk faktörlerini iyi bilmeleri, yeniliklere ve değişikliklere açık olmaları, hileli finansal raporlamanın tespiti ve önlenmesi noktasında daha etkili olabileceği bulgularına ulaşılmıştır.

Uçma (2011) çalışmasında, hileli finansal raporlamada denetçi sorumluluğunun ortaya çıkarılması ve denetçi sorumluluğundan yola çıkarak denetim mekanizmasının önemini ortaya koymayı amaçlamıştır. Çalışma sonucunda, hileli finansal raporlamada iç denetçi ve denetim komitesi sorumluluğu ortaya çıkarılmakta ve bu noktadan hareketle kurumsal olarak ortaya konan model yapısal eşitlik modeli ile test edilmektedir.

Kiracı ve diğerleri (2014) çalışmalarında, iç denetçilerin hile ve usulsüzlükler karşısındaki sorumluluklarını teorik olarak incelemişlerdir.

Brown (1983), Carey vd. (2000), Carcello vd.'nin (2005) yıllarında yaptıkları çalışmalarda, iç denetçilerin hileli finansal raporlamayı önlemedeki etkileri incelenmiştir. Bu çalışmalar sonrasında iç denetçilerin, hileli finansal raporlamanın önlenmesinde doğrudan etkiye sahip oldukları ortaya konulmuştur.

Doyle vd.'nin 2007 yılında yaptıkları çalışmalarında ise işletmedeki iç denetim mekanizmasının eksikliğinin ve etkin çalışamamasının, hileli finansal raporlamaya yol açtı̆̆ını ortaya koymuşlardır

\section{ARAŞTIRMANIN METODOLOJİSI}

Araştırmanın metodolojisine yönelik açıklamalar özet halinde aşağıda yer almaktadır.

\section{1. Araştırmanın Önemi ve Amacı}

Yolsuzluğun ekonomi ve toplum için büyük bir sorun olmasından dolayı bu durumu önlemek için gerek ülkeler, hükümetler ve gerekse işletmeler imkânları çerçevesinde çeşitli önlemler almaktadır. Bu anlamda işletmeler, ağırlıklı olarak muhasebe hileleri biçiminde yaşadıkları sorunu azaltmak amacıyla kendi denetim organlarını (denetim komitesi, iç denetim, risk yönetimi, anonim ihbar hatları, vb.) oluşturmaya veya var olanları etkinleştirmeye çalışmaktadır. İç denetim, işletmelerin hileleri bulma ve tespiti konusunda hem kaynak hem de zaman ve maliyet tasarrufu sağladığından dolayı kurum için önemli bir uygulamadir. 
Araştırmanın birbiriyle ilintili iki amacı bulunmaktadır:

1) Hileli finansal işlemlerin tespit edilme skklıklarının düzeyi nedir?

2) İç denetim sisteminin hileli finansal raporlamayı önlemedeki rolüne yönelik ifadelere katılımcıların katılım düzeyi nedir?

\section{2. Araştırmanın Modeli, Evreni ve Örneklemi}

Araştırmanın amaçlarına ulaşabilmek için tesadüfü olarak seçilen katılımcılara anket yöntemi uygulanmıştır. Anket formu oluşturulurken konuyla ilgili literatür taraması yapılarak daha önceden yapılmış çalışmalardan (Çıtak 2013: 140-141) yararlanılmıştır. Ayrıca ön araştırma amacıyla bağımsız denetçilerle görüşülmüş ve araştırma amacına yönelik olarak hazırlanan anket formundaki ifadeler hakkında görüşleri alınmıştır.

Anket formunda, $A$ Bölümünde katılımcıların demografik yapılarını ölçmeye yönelik 10 ifade, $B$ Bölümünde hileli finansal işlemlerin tespit edilme sıklkklarının düzeyini ölçmeye yönelik 26 ifade ve $C$ Bölümünde iç denetim sisteminin hileli finansal raporlamay1 önlemedeki rolünü ölçmeye yönelik 13 ifade olmak üzere toplam 49 ifade yer almaktadır.

Bağımsız denetim firmasında çalışan denetçi sayılarının tam olarak tespit edilememesinden dolayı, araştırmanın örneklem büyüklüğü ana kütledeki birim sayısı $(\mathrm{N})$ bilinmiyor olarak hesaplanmıştır. Bu hesaplama aşağıdaki formül yardımıyla yapılmıştır (Karagöz 2014: 151).

Ana kütledeki birim $(\mathrm{N})$ bilinmiyor ise;

$$
\begin{aligned}
& n=\frac{p^{\prime} \cdot q^{\prime} \cdot t_{\alpha / 2}^{2}}{d^{2}} \\
& n=\text { Örneklem Büyüklüğü }
\end{aligned}
$$

$p=$ Ana kütledeki incelenen olayın gözlenme oranı (gerçekleşme olasılı̆̆), incelenen olayın örneklemde gözlenme oranı ise $p^{x}$ biçiminde gösterilir. Bu oran bilinmediği durumda 0,50 olarak kabul edilir.

$q=1-p$ : Ana kütledeki incelenen olayın gözlenmeme oranı (gerçekleşmeme olasılı̆g), incelenen olayın örneklemde gözlenmeme oranı ise $q^{\prime}=1-p^{\prime}$ biçiminde gösterilir.

$t_{\sigma / 2}^{2}=$ Belirli bir anlamll1k düzeyinde, $\mathrm{T}$ tablosuna göre bulunan teorik değer. Diğer bir ifadeyle, istenilen olasılık düzeyi için $\mathrm{T}$ değeridir ( $\alpha=0,10$ için 1,64$)$.

d: Tahmin edilecek olan ana kütle oranı ile aynı ana kütleden alınan örneklem oranı arasındaki sapma miktarı $\left(p^{\prime}-p\right)$,

Bu durumda örneklem sayıs1,

$$
n=\frac{0,50.0,50.1,64^{2}}{0,05^{2}}=\frac{0,6724}{0,0025}=268,96
$$


Yapılan çalışmada ulaşılan sayı 300 olmuştur. Örneklem büyüklüğü araştırma evreni için yeterli olmaktadır.

\subsection{Araştırmada Kullanılan İstatistiksel Teknikler}

Anket verilerinin analizinde, SPSS 22 for Windows (Social Package Statiscal Science) istatistiksel paket programından yararlanılmıştır.

Daha öncede ifade edildiği gibi araştırmanın birbiriyle ilintili iki amacı bulunmaktadır. Katılımcılardan anketin B bölümünde yer alan 26 ifadeye katılım düzeylerini Daima (5), Siklıkla (4), Çok (3), Bazen (2) ve Hiç (1) şeklinde; C bölümünde yer alan 13 ifadeye ait katılım düzeylerini ise Kesinlikle Katılıyorum (5), Katılıyorum (4), Kararsızım (3), Katılmıyorum (2) ve Kesinlikle Katılmıyorum (1) şeklinde belirtmeleri istenmiştir.

Örnekleme ait ham verilerin çözümlenmesi SPSS 22 paket programı ile betimsel istatistik yöntem ve teknikleri kullanılarak yapılmıştır. Çözümlenen verilerin tablolar halinde ifade edilmesinde demografik yapıya ait cevapların frekans (f) ve yüzdeleri (\%) ve çalışmanın iki amacına yönelik olarak hazırlanan ifadelere ait cevapların ise aritmetik ortalama $(\bar{x})$ ve standart sapma (ss) değerleri dikkate alınmıştır.

Katılımcıların, ankette bulunan her bir ifadeye, hangi düzeyde katıldığı ya da görüşlerini bölümlerdeki nitelemelerden hangisine girdiği yapılan sınıflama ölçeği ile belirlenmiştir. Sınıflama ölçeğinin oluşturulmasında;

\section{Aralık Genişliği (a) = Dizi Genişliği $\div$ Yapılacak Grup Sayısı}

formülü kullanılmıştır (Tekin, 1987; 262). Bu formüle göre oluşturulan ölçekte, nitelik düzeyi ve puan değerleri ile değer aralıkları her bölüm için aşağıdaki Tablo1'de gösterilmiştir.

$\mathrm{a}=4 / 5$ ise $\mathrm{a}=0,80$ bulunur.

Tablo 1. Anketteki İfadelerin Puanları ve Değer Aralıkları

\begin{tabular}{|c|c|c|}
\hline Nitelik Düzeyi & Puan & Değer Aralıkları \\
\hline Daima & \multirow{2}{*}{5} & \multirow{2}{*}{$4,20-5,00$} \\
\hline Kesinlikle Katıliyorum & & \\
\hline Siklikla & \multirow{2}{*}{4} & \multirow{2}{*}{$3,40-4,19$} \\
\hline Katıliyorum & & \\
\hline Çok & \multirow{2}{*}{3} & \multirow{2}{*}{$2,60-3,39$} \\
\hline Kararsızım & & \\
\hline Bazen & \multirow{2}{*}{2} & \multirow{2}{*}{$1,80-2,59$} \\
\hline Katılmiyorum & & \\
\hline Hiç & \multirow{2}{*}{1} & \multirow{2}{*}{$1,00-1,79$} \\
\hline Kesinlikle Katılmıyorum & & \\
\hline
\end{tabular}

Bağımsız denetçilere uygulanan anket formunun geçerlilik ve güvenirliğinin istenen değerlerde olup olmadığı Cronbach's Alpha iç tutarlılık katsayısı ile tespit edilmeye çalışılmış ve analiz sonucu Tablo 2'de gösterilmiştir. 
Tablo 2. Cronbach's Alpha Iç Tutarlılık Katsayısı

\begin{tabular}{|l|l|l|}
\hline Madde Sayısı & İç Tutarlılık Katsayısı & Güvenirlik Durumu \\
\hline 39 & 0,84 & Oldukça Güvenilir. \\
\hline
\end{tabular}

Tablo 2'de görüldüğü gibi Cronbach's Alpha iç tutarlılık katsayısı olarak hesaplanmıştır. Bu sonuca göre söz konusu 39 ifadenin bir bütün olarak, ölçmek istenen olguyu ölçmede "oldukça güvenilir" olduğu söylenebilir (https://kemaldoymus.files.wordpress.com).

\section{BULGULAR}

Araştırmanın bu aşamasında, bağımsız denetim kuruluşunda çalışan bağımsız denetçilere anket formunun uygulanmasıyla elde edilen veriler, belirtilen istatiksel tekniklerle analiz edilmiş ve analiz sonuçları tablolar halinde sunularak yorumlanmaya çalışılmıştır.

Bulgular üç aşamalı olarak ele alınmıştır. Birinci Aşamada, örneklem grubunun demografik yapısı belirlenmeye çalışılmıştır. İkinci Aşamada, katılımcıların, hileli finansal işlemleri tespit etme sıklığına ilişkin bulgular üzerinde durulmuştur. Üçüncü Aşamada ise katılımcıların, iç denetim sisteminin hileli finansal raporlamayı önlemedeki rolüne yönelik ifadelere ait katılım düzeylerine ilişkin bulgular değerlendirilmiştir.

\section{I. Demografik Yapıya İlişkin Bulgular}

Katılımcıların demografik sorulara ait cevapların istatistik sonuçları Tablo 3'te yer almaktadır.

Tablo 3. Katılımcıların Demografik Özellikleri

\begin{tabular}{|c|c|c|c|c|c|}
\hline Cinsiyet Dağılımı & $\begin{array}{l}\text { Frekans } \\
\text { (f) }\end{array}$ & $\begin{array}{l}\text { Yüzde } \\
(\%)\end{array}$ & Eğitim Düzeyi & $\begin{array}{l}\text { Frekans } \\
\text { (f) }\end{array}$ & $\begin{array}{l}\text { Yüzde } \\
(\%)\end{array}$ \\
\hline Kadın & 117 & 39,0 & Lisans & 242 & 80,7 \\
\hline Erkek & 183 & 61,0 & Y. Lisans & 45 & 15,0 \\
\hline \multirow[t]{2}{*}{ Toplam } & 300 & 100 & Doktora & 13 & 4,3 \\
\hline & & & Toplam & 300 & 100 \\
\hline Yaş & $\begin{array}{l}\text { Frekans } \\
\text { (f) }\end{array}$ & $\begin{array}{l}\begin{array}{l}\text { Yüzde } \\
(\%)\end{array} \\
\end{array}$ & $\begin{array}{l}\text { Meslek Unvanı } \\
\text { Dağılımı }\end{array}$ & $\begin{array}{l}\text { Frekans } \\
\text { (f) }\end{array}$ & $\begin{array}{l}\begin{array}{l}\text { Yüzde } \\
(\%)\end{array} \\
\end{array}$ \\
\hline 24 ve aşağıs1 & 16 & 5,3 & $\begin{array}{l}\text { S. Ortak Baş } \\
\text { Denetçi }\end{array}$ & 5 & 1,7 \\
\hline $25-34$ aras 1 & 147 & 49,0 & Baş Denetçi & 66 & 22,0 \\
\hline $35-44$ aras1 & 100 & 33,3 & Kıdemli Denetçi & 82 & 27,3 \\
\hline 45 - ve üstü & 37 & 12,4 & Denetçi & 147 & 49,0 \\
\hline \multirow[t]{2}{*}{ Toplam } & 300 & 100 & Diğer & 0 & 0 \\
\hline & & & Toplam & 300 & 100 \\
\hline Deneyim & $\begin{array}{l}\text { Frekans } \\
\text { (f) }\end{array}$ & $\begin{array}{l}\text { Yüzde } \\
(\%)\end{array}$ & Faaliyet Süresi & $\begin{array}{l}\text { Frekans } \\
\text { (f) }\end{array}$ & $\begin{array}{l}\begin{array}{l}\text { Yüzde } \\
(\%)\end{array} \\
\end{array}$ \\
\hline $1-5$ yil & 29 & 9,7 & $1-5$ yil & 0 & 0 \\
\hline $6-9 \mathrm{yll}$ & 118 & 39,3 & $6-9$ yil & 16 & 5,3 \\
\hline $10-15 \mathrm{yll}$ & 87 & 29,0 & $10-15$ yil & 64 & 21,3 \\
\hline $16-19$ yıl & 38 & 12,7 & $16-19$ yil & 66 & 22,0 \\
\hline 20 yıl ve üzeri & 28 & 9,3 & 20 yıl ve üzeri & 154 & 51,4 \\
\hline Toplam & 300 & 100 & Toplam & 300 & 100 \\
\hline
\end{tabular}




\begin{tabular}{|c|c|c|c|c|c|}
\hline Firma Türü & $\begin{array}{l}\text { Frekans } \\
\text { (f) }\end{array}$ & $\begin{array}{l}\text { Yüzde } \\
(\%)\end{array}$ & Personel Sayısı & $\begin{array}{l}\text { Frekans } \\
\text { (f) }\end{array}$ & $\begin{array}{l}\text { Yüzde } \\
(\%)\end{array}$ \\
\hline Bölgesel- Yerel & 27 & 9,0 & $1-5$ Personel & 0 & 0 \\
\hline Ulusal & 173 & 57,3 & $6-9$ Personel & 8 & 2,7 \\
\hline Uluslararası & 100 & 33,3 & $10-16$ Personel & 96 & 32,0 \\
\hline \multirow[t]{2}{*}{ Toplam } & 300 & 100 & $\begin{array}{lrl}16 & \text { ve } & \text { üzeri } \\
\text { Personel } & \end{array}$ & 196 & 65,3 \\
\hline & & & Toplam & 300 & 100 \\
\hline Unvanı & $\begin{array}{l}\text { Frekans } \\
\text { (f) }\end{array}$ & $\begin{array}{l}\text { Yüzde } \\
(\%)\end{array}$ & Şirket Merkezi & Frekans (f) & \begin{tabular}{l|l}
$\begin{array}{l}\text { Yüzde } \\
(\%)\end{array}$ \\
\end{tabular} \\
\hline SMMM & 147 & 49,0 & Adana & 4 & 1,3 \\
\hline YMM & 153 & 51,0 & Ankara & 75 & 25,0 \\
\hline Toplam & 300 & 100 & Antalya & 12 & 4,0 \\
\hline \multirow{5}{*}{$10 p$ pani } & & & Bursa & 8 & 2,7 \\
\hline & & & Kayseri & 17 & 5,7 \\
\hline & & & İstanbul & 164 & 54,6 \\
\hline & & & İzmir & 20 & 6,7 \\
\hline & & & Toplam & 300 & 100 \\
\hline
\end{tabular}

Tablo 3'te görüldüğü gibi ankete katılan katılımcıların öne çıkan demografik özellikleri aşağıdaki gibi özetlenebilir: yaş grubundadır.

Bağımsız denetim faaliyetini gerçekleştiren denetçilerin yaklaşık \%85'i orta

Bağımsız denetim faaliyetini gerçekleştiren denetçilerin yarıdan fazlasının mesleki deneyim süresi 6-15 yıl arasındadır. etmektedir.

Bağımsız denetim kuruluşlarının yarıdan fazlası en az 16 personel istihdam

$\% 57,3$ 'ü ulusal, sonrasinda ise \%33,3'ü uluslararası, kalan \%9'unun ise bölgesel-yerel firma olduğu tespit edilmiştir.

$>\quad$ Katılımcıların çoğunluğu $(\% 54,6)$ İstanbul'da görev yapmaktadır.

\section{2. Hileli Finansal İşlemlerin Tespit Edilme Sıklıklarının Düzeyine İliş̧kin Bulgular}

Ankete katılan bağımsız denetim elemanlarının, "Hileli Finansal İşlemlerin Tespit Edilme Sıklı̆̆g'na ilişkin ifadelere katılım düzeyleri belirlenmeye çalışılmıştır. Katılımcıların bu ifadelere verdikleri cevaplara ilişkin, aritmetik ortalama $(\overline{\boldsymbol{x}})$ ve standart sapma (ss) değerleri ve değerlerin karşıllğ̆ olan katılım düzeyleri Tablo 4 'te verilmiştir. 
Tablo 4. Hileli Finansal İşlemlerin Tespit Edilme Sıklığına Ait Görüşlerin İstatistikleri

\begin{tabular}{|c|c|c|c|c|c|}
\hline $\begin{array}{c}\text { Sira } \\
\text { No }\end{array}$ & Hileli Finansal İşlemler & $\mathbf{n}$ & $(\bar{x})$ & (ss) & $\begin{array}{l}\text { Katılım } \\
\text { Düzeyi }\end{array}$ \\
\hline 1 & $\begin{array}{l}\text { Maddi duran varlıklar için ayrılan amortismanların } \\
\text { yüksek gösterilmesi }\end{array}$ & 300 & 3,20 & 1,35 & Çok \\
\hline 2 & Stok değer düşüklüğünün ayrılmamas1 & 300 & 3,18 & 1,17 & Çok \\
\hline 3 & Varlıkların yanlış hesap gruplarına kaydedilmesi & 300 & 3,13 & 0,79 & Çok \\
\hline 4 & Bilanço tarihinden sonraki olayların açıklanmaması & 300 & 3,09 & 1,08 & Çok \\
\hline 5 & $\begin{array}{l}\text { Değerini kaybetmiş̧ varlıkların } \\
\text { çıkartılmaması }\end{array}$ & 300 & 3,08 & 1,04 & Çok \\
\hline 6 & $\begin{array}{l}\text { Değerini kaybetmiş varlıklardaki değer düşüklüğünün } \\
\text { kayda alınması/alınmaması }\end{array}$ & 300 & 2,80 & 1,27 & Çok \\
\hline 7 & $\begin{array}{l}\text { Şarta bağlı yükümlülüklerin } \text { bildirilmesinin ihmal } \\
\text { edilmesi }\end{array}$ & 300 & 2,77 & 1,17 & Çok \\
\hline 8 & Ticari alacakların yüksek gösterilmesi & 300 & 2,72 & 0,84 & Çok \\
\hline 9 & $\begin{array}{l}\text { Alış iadelerinin ve indirimlerinin } \\
\text { kaydedilmesi }\end{array}$ & 300 & 2,42 & 0,91 & Bazen \\
\hline 10 & $\begin{array}{l}\text { Muhasebe politikalarındaki değişimlerin açıklanmaması } \\
\text { ve yetersiz kalması }\end{array}$ & 300 & 2,40 & 1,33 & Bazen \\
\hline 11 & $\begin{array}{l}\text { V.U.K kapsamında aktifleştirilmesi gereken giderler } \\
\text { dışındaki harcamaların aktifleştirilmesi }\end{array}$ & 300 & 2,39 & 1,43 & Bazen \\
\hline 12 & İlişkili taraflara, işlemlerin yeterli açıklanmaması & 300 & 2,37 & 1,38 & Bazen \\
\hline 13 & Faturalanan fakat müşteri adına stokta tutulan mallar & 300 & 2,30 & 0,82 & Bazen \\
\hline 14 & Yoldaki malların yüksek gösterilmesi & 300 & 2,24 & 0,75 & Bazen \\
\hline 15 & $\begin{array}{l}\text { Maddi duran varlıklar için ayrılan amortismanların düşük } \\
\text { gösterilmesi veya hiç gösterilmemesi }\end{array}$ & 300 & 2,12 & 0,78 & Bazen \\
\hline 16 & Cari dönem giderlerinin önceki döneme kaydırılması & 300 & 2,10 & 0,49 & Bazen \\
\hline 17 & Stok maliyetlerinin uzun yıllara yayılmas 1 & 300 & 2,10 & 0,86 & Bazen \\
\hline 18 & Faaliyet giderlerinin aktifleștirilmesi & 300 & 2,03 & 0,43 & Bazen \\
\hline 19 & $\begin{array}{l}\text { İ̀sletmelerin birleşme veya satın alınma sürecinde } \\
\text { varlıkların düşük gösterilmesi }\end{array}$ & 300 & 2,02 & 0,80 & Bazen \\
\hline 20 & Konsinye alınan malların stoklara kaydedilmesi & 300 & 1,85 & 0,62 & Bazen \\
\hline 21 & Varlıklar için ayrılan karşı1ıkların azaltılması & 300 & 1,83 & 0,51 & Bazen \\
\hline 22 & Hayali stok oluşturulması & 300 & 1,75 & 1,06 & Hiç \\
\hline 23 & $\begin{array}{l}\text { Nakit ve menkul kıymetlerin fiktif olarak yüksek } \\
\text { gösterilmesi }\end{array}$ & 300 & 1,71 & 0,88 & Hiç \\
\hline 24 & $\begin{array}{l}\text { Maddi duran varlıkların gerçek değerinin üstünde } \\
\text { değerlenmesi }\end{array}$ & 300 & 1,64 & 0,49 & Hiç \\
\hline 25 & Hayali gelir kaydedilmesi & 300 & 1,40 & 0,52 & Hiç \\
\hline 26 & $\begin{array}{l}\text { İ̀sletmelerin birleşme veya satın alınma sürecinde } \\
\text { varlıkların yüksek gösterilmesi }\end{array}$ & 300 & 1,27 & 0,48 & Hiç \\
\hline \multicolumn{2}{|r|}{$\begin{array}{l}\text { TOPLAM KATILIM DÜZEYİ } \\
\end{array}$} & 300 & 2,32 & $\mathbf{0 , 8 9}$ & Bazen \\
\hline
\end{tabular}

Tablo 4'te katılımcıların, hileli finansal işlemlerin tespit edilme sıklığına ilişkin görüşlerine genel olarak bakıldığında ifadelerin tümüne katılım düzeylerinin aritmetik ortalamasının 2,32 ve standart sapmasının 0,89 olduğu görülmektedir. Bu değerler, hileli finansal işlemlerin tespit edilme sıklığına ilişkin görüşleri genel katılımının "bazen" düzeyinde olduğunu göstermektedir. 
Tablo 4'ten katılımcıların, 1-8 arasındaki hile türleriyle “çok” karşılaşmış oldukları; 9-21 arasında yer alan hileli finansal işlemlere "bazen" karşılaştıkları ve 22-26 arasındaki finansal hilelerle ise "hiç" karşılaşmadıkları görülmektedir. Aynı tabloda hileli finansal işlemlerin hiç birisi için sıklık düzeyinin en yükseklerinden olan "Daima" ve "Stklıkla" seçeneklerinin tercih edilmemesi de bir başka önemli bulgudur.

Bu hile türlerinin bazılarında amaç kârı yüksek göstermek iken bazılarında ise düşük göstermektir. İşletmeler çoğunlukla planlanan hedef kapsamında hareket etme meyli gösterdiklerinden farklı niyetlerle kâr rakamı üzerinde manipülatif uygulama içerisinde yer almaktadırlar. Özelikle "çok" düzeyinde katılımın olduğu hileler açısından değerlendirme yapıldığında da durumun farklı olmadığı; kâr rakamına dolayısıyla işletmenin performansına yönelik düşüncelerin hile uygulamalarını yönlendirdiği görülmektedir. Özetle salt kârı düşürüp daha az vergi ödeme düşüncesi ile değil tam tersi düşünce ile yani kârı yüksek gösterip -daha fazla vergi ödemeyi göze alma pahasına- şirketi olduğundan başarılı sunma düşüncesi de hileli işlemlerde kendisini göstermektedir. Elbette ki hile olarak düşünülen uygulamaların bir kısmının "hata" ile olduğu; bir kısmının da bilgi eksikliği veya yanlış bilgi neticesinde gerçekleştiği de gözden uzak tutulmamalıdır. Ancak hile ile hatanın ayrımını yapmak da oldukça zordur.

\section{3. İç Denetim Sisteminin Hileli Finansal Raporlamayı Önlemedeki Rolüne İlişkin Bulgular}

Ankete katılan bağımsız denetim elemanlarının, " $\dot{I}_{c ̧}$ Denetim Sisteminin Hileli Finansal Raporlamayı Önlemedeki Rolüne” ilişkin ifadelere katılım düzeyleri belirlenmeye çalışılmıştır. Katılımcıların bu ifadelere verdikleri cevaplara ilişkin, aritmetik ortalama $(\bar{x})$ ve standart sapma (ss) değerleri ve değerlerin karşılı̆̆ı olan katılım düzeyleri Tablo 5'te verilmiştir.

Tablo 5. İç Denetim Sisteminin Hileli Finansal Raporlamayı Önlemedeki Rolüne İlişkin Görüşlerin İstatistikleri

\begin{tabular}{|l|l|l|l|l|l|}
\hline $\begin{array}{l}\mathbf{Z} \\
\tilde{\mathbf{n}}\end{array}$ & $\begin{array}{l}\text { İç Denetim Sisteminin Hileli Finansal } \\
\text { Raporlamayı Önlemedeki Rolüne İlişkin İfadeler }\end{array}$ & $\mathbf{n}$ & $(\overline{\boldsymbol{x}})$ & $(\mathbf{s s})$ & Katılım Düzeyi \\
\hline $\mathbf{1}$ & $\begin{array}{l}\text { İç denetçinin denetim standartlarını bilmemesi hileli } \\
\text { finansal raporlama yapılma riskini artırır. }\end{array}$ & 300 & 4,68 & 0,47 & Kesinlikle Katılıyorum \\
\hline $\mathbf{2}$ & $\begin{array}{l}\text { Zayıf bir iç denetim yapısı hileli finansal raporlama } \\
\text { riskini artırır. }\end{array}$ & 300 & 4,60 & 0,57 & Kesinlikle Kattlıyorum \\
\hline $\mathbf{3}$ & $\begin{array}{l}\text { İç denetçinin iyi bir eğitime ve mesleki yeterliliğe } \\
\text { sahip olması hileli finansal raporlama yapılma riskini } \\
\text { azaltır. }\end{array}$ & 300 & 4,53 & 0,50 & Kesinlikle Katıllyorum \\
\hline $\mathbf{4}$ & $\begin{array}{l}\text { İç denetçinin yönetim ile birlikte hilelere karşı önlem } \\
\text { alması hileli finansal raporlama riskini azaltır. }\end{array}$ & 300 & 4,44 & 0,57 & Kesinlikle Katılıyorum \\
\hline $\mathbf{5}$ & $\begin{array}{l}\text { İç denetçi ile denetim komitesi arasındaki iletişimin } \\
\text { iyi olması hileli finansal raporlama yapılma riskini } \\
\text { azaltır. }\end{array}$ & 300 & 4,43 & 0,57 & Kesinlikle Katılıyorum \\
\hline $\mathbf{6}$ & $\begin{array}{l}\text { İç denetim ve denetim komitesi arasındaki raporlama } \\
\text { hileli finansal raporlama riskini azaltır. }\end{array}$ & 300 & 4,40 & 0,49 & Kesinlikle Katılıyorum \\
\hline $\mathbf{7}$ & $\begin{array}{l}\text { Etkin bir iç denetim birimi bulunan şrketlerde hileli } \\
\text { finansal raporlama riski azalır. }\end{array}$ & 300 & 4,38 & 0,61 & Kesinlikle Katılıyorum \\
\hline
\end{tabular}




\begin{tabular}{|c|c|c|c|c|c|}
\hline 8 & $\begin{array}{l}\text { İç denetçiyle bağımsız denetçi arasındaki iletişimin } \\
\text { iyi olmaması hileli finansal raporlama yapılma riskini } \\
\text { artırır. }\end{array}$ & 300 & 4,35 & 0,52 & Kesinlikle Katılıyorum \\
\hline 9 & $\begin{array}{l}\text { İç denetçinin mesleki etik kurallarını bilmesi hileli } \\
\text { finansal raporlama yapılma riskini azaltır. }\end{array}$ & 300 & 4,26 & 0,54 & Kesinlikle Katılıyorum \\
\hline 10 & $\begin{array}{l}\text { İç denetçinin tarafsızlığı hileli finansal raporlama } \\
\text { riskini azaltır. }\end{array}$ & 300 & 4,01 & 0,73 & Katıliyorum \\
\hline 11 & $\begin{array}{l}\text { Hile önlemede sorumluluk sadece iç denetçiye ait } \\
\text { değildir. }\end{array}$ & 300 & 3,96 & 0,33 & Katıliyorum \\
\hline 12 & $\begin{array}{l}\text { İç denetimin iyi veya yeterli olmadığı şirketlerde } \\
\text { denetim komitesi sorumluluğunu tam manasıly } \\
\text { yerine getirememektedir. }\end{array}$ & 300 & 3,58 & 0,72 & Katıliyorum \\
\hline 13 & $\begin{array}{l}\text { Meslektaşlar arasında "hileyi önlemeye dönük } \\
\text { faaliyetleri gerçekleştirmek sadece yöneticilere aittir" } \\
\text { düşüncesine sahip olanlar vardır. }\end{array}$ & 300 & 3,11 & 0,71 & Kararsızım \\
\hline \multicolumn{2}{|r|}{ TOPLAM KATILIM DÜZEYİ } & 300 & 4,19 & $\mathbf{0 , 5 7}$ & Katılıyorum \\
\hline \multicolumn{6}{|c|}{ 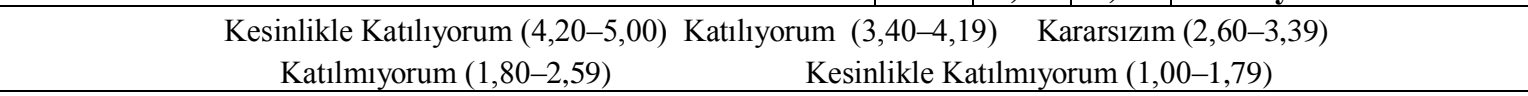 } \\
\hline
\end{tabular}

Tablo 5'te katılımcıların, iç denetimin hileli finansal raporlamayı önlemedeki rolüne ilişkin görüşlerine genel olarak bakıldığında ifadelere katılım düzeylerin aritmetik ortalamasının 4,19 ve standart sapmasının 0,57 olduğu görülmektedir. $\mathrm{Bu}$ değerler, katılımcıların iç denetimin hileli finansal raporlamayı önlemdeki rolüne ilişkin ifadelere görüşlerinin genel katılımının "katılıyorum" düzeyinde olduğunu göstermektedir.

Tablo 5'ten katılımcıların iç denetim sisteminin hileli finansal raporlamayı önlemedeki rolüne ilişkin, 1-9 arasındaki ifadelere "kesinlikle katılıyorum"; 10-12 arasında yer alan ifadelere "katılıyorum" ve sadece 13 no.lu ifadeye ise "kararsızım" görüş bildirdikleri anlaşılmaktadır. Kararsızım düzeyinde görüş bildirilen ifadenin aritmetik ortalamasının katılıyorum düzeyine çok yakın olduğu da dikkatlerden kaçmamalıdır. Aynı tabloda iç denetim sisteminin hileli finansal raporlamayı önlemedeki rolüne ilişkin ifadelerin hiç birisi için katılım düzeyinin en düşüklerinden olan "katılmıyorum "ve "kesinlikle katılmıyorum" seçeneklerinin tercih edilmemesi de bir başka önemli bulgudur.

İç denetim sisteminin varlığının amaçları arasında, muhasebe ilke ve kavramlarına uyulmasını sağlamak suretiyle hileli finansal işlemleri dolayısıyla hileli finansal raporlama riskini azaltmak yer almaktadır. Elde edilen bulgulardan hareketle, iç denetim sisteminin hedeflerinden biri olan hileli finansal işlemleri azaltma/ortadan kaldırmada önemli bir etkiye ve katkıya sahip olduğu söylenebilir

İç denetçi, işletmenin bir personeli olup ücretini işletmeden aldığından denetim faaliyetlerinde objektiflik, bağımsızlık ve tarafsızlık açısından bir sorun yaşanabilir. Ancak bu düşünceyle, iç denetim sistemine yönelmemek de doğru bir davranış olmayacaktır. Ayrıca iç denetim sistemi ortaya çıkarılacak hatalı finansal işlemlerin sebebi, hangi yanlış bilgiyle yapıldığ1 ve nasıl düzeltileceği, ilgili kişilere anlatılarak doğru işlemin öğretilmesi açısından da bir faydası olacağı gözden uzak tutulmamalıdır.

$\mathrm{Bu}$ sonuçlardan yola çıkılırsa katılımcıların, işletme faaliyetlerini, yöneticilerini, çalışanlarını ve her türlü işlemi yakından gözleyen iç denetçilerin hata ve hilelerin ortaya çıkarılmasındaki konumunun önemini kabul ettiklerini ve iç denetçiler ile işbirliği yapılması 
gerekliliğine inandıklarını da göstermektedir. İç denetimin etkinleştirilmesi ile katılımcıların iş yoğunluğunun azalabileceği ve katılımcıların sorumluluğu yönetimle paylaşma eğilimlerinin de artabileceği söylenebilir.

İç denetçinin; mesleki eğitim ve yeteneğe sahip olması, bağımsız denetçi ve denetim komitesi ile iş birliği içinde bulunması, iç denetim ve bağımsız denetim standartlarına uyması ve elde ettiği bilgileri tarafsız olarak bildirmesi gerekmektedir. Böyle hareket edilen bir iç denetim sistemine ve iç denetçiye sahip olan işletmelerde hileli finansal işlemlerin önüne geçilmesi daha kolay olacaktır. $\mathrm{Bu}$ da işletmenin iç ve dış taraflarına sunulan bilginin kalitesini artıracak, hatalı kararların azalmasına katkı sağlayacaktır.

\section{SONUÇ}

Hileli finansal raporlama olayları toplumun her kesiminde, işletmelerden yansıyan bilgilere olan güveni azaltmış ve bu durum oldukça önemli bir sorun halini alarak denetim mesleğine yönelik şüpheleri de artırmıştır. Özellikle 2000'li yıllarda yaşanan finansal skandallar ile birlikte denetim mesleği derinden derine sorgulanmış, denetçilerin böyle bir hile olayını ortaya çıkarmaması ise ciddi eleştirilere sebep olmuştur. Bütün bu olaylar neticesinde muhasebe, denetim ve kurumsal yönetim alanlarında ardı ardına düzenlemelere gidilmiştir.

Finansal tablo kullanıcılarına güvenilir bilgi sunulmasında yardımcı olabilecek ve risk faktörlerini belirleyerek riskleri en aza indirebilecek önemli unsurlardan biri de iç denetim sistemidir.

İç denetim sisteminde yer alan iç denetçinin, bağımsız ve tarafsız bir şekilde sorumluluklarını yerine getirmesi, yeterli ve azami bir mesleki bilgiye sahip olması hilenin tespit edilmesini ve önlenmesini kolaylaştıracaktır.

Bu çalışmada, öncelikle hile, muhasebede hile, hileli finansal raporlama, iç denetim konuları hakkında teorik açıklamalarda bulunulmuştur. Türkiye'de faaliyet gösteren bağımsız denetim şirketlerinde çalışan bağımsız denetçilere bir anket uygulanarak, hileli finansal işlemlerin tespit edilme sıklığına ve iç denetim sisteminin hileli finansal raporlamayı önlemedeki rolü tespit edilmeye çalışılmıştır.

Katılımcıların, hileli finansal işlemlerden, "Maddi duran varlıklar için ayrılan amortismanların yüksek gösterilmesi", "Stok değer düşüklügünün ayrılmaması" ve "Varlıkların yanlış hesap gruplarına kaydedilmesi" işlemleriyle "Çok" sıklıkla karşılaştıkları ayrıca "Maddi duran varlıkların gerçek değerinin üstünde değerlenmesi", "Hayali gelir kaydedilmesi" ve "İşletmelerin birleşme veya satın alınma sürecinde varlıkların yüksek gösterilmesi” işlemlerine "Hiç" rastlamadıkları bulgusu elde edilmiştir (Tablo:4).

Araştırmanın sonucunda elde edilen diğer bulgular ise iç denetçilerin eğitimli ve mesleki yeterliliğe sahip olmalarının, denetim standartlarını iyi bilmelerinin, bağımsız denetçilerle ve denetim komitesiyle ilişkilerinin iyi olmalarının, yönetimle birlikte hilelere karşı önlem almalarının ve mesleki etik kurallarını iyi bilmelerinin hileli finansal raporlamanın önlenmesinde etkili olabileceğidir. Ayrıca katılımcılar, hileleri önleme yükümlülügünün sadece iç denetçiye yüklenmesini kabul etmemekte buna karşılık sorumluluğun yöneticilere ait olduğu noktasında ise kararsız kalmaktadırlar (Tablo:5). 
Çalışmada elde edilen bulgulara dayanarak aşağıdaki önerilerde bulunulabilir: oluşturulmalıdır.

Hileli işlemlerin önlenmesi için bağımsız ve tarafsız iç denetim birimi

İç denetçinin her türlü hile ve usulsüzlük karşısında kimseden etkilenmeden hareket etmesi için uygun çalışma şartları oluşturulmalıdır.

İç denetçiler, iç denetim standartlarına uygun hareket ettiklerinde sorumlulukların daha iyi yerine getireceklerdir.

$>\quad$ İç denetçilerin yeniliklere açık ve teknolojik gelişmeleri yakından takip etmeleri gerekmektedir.

$>\quad$ İç denetçilere gerekli muhasebe ve finansal raporlama, teknik denetimler, karşılaşılabilecek hilelerle ilgili eğitimler verilmelidir.

$>\quad$ İç denetçiler, finansal hile türleriyle ilgili bilgi sahibi olmalıdırlar.

$>\quad$ İç denetçiler, meydana gelen muhasebe ve denetim skandallarının hangi sebeplerden ve hangi aksaklıklardan kaynaklandığını ve bu gibi durumları önleyebilmek için nelerin yapılması gerektiğini öğreten eğitimlere tabi tutulmalıdırlar.

\section{KAYNAKLAR}

Akyel, Recai (2010), "Yönetimde İç Kontrol, İç Denetim ve Dış Denetim Fonksiyonlarının Birbirileri İle İlişkileri ve Türk Kamu Yönetiminde Uygulamalarının Değerlendirilmesi”, Çukurova Üniversitesi Sosyal Bilimler Enstitüsü Dergisi, Cilt:19, Say1: 3, ss. 1-22.

Atmaca, Metin (2012), "Muhasebe Skandallarının Önlenmesinde İç Kontrol Sisteminin Etkinleştirilmesi”, Afyon Kocatepe Üniversitesi İ̈BF dergisi, Cilt: XIV, Sayı:1, ss. 191-205.

Bayrakl1, Hüseyin - Erkan, Mehmet- Elitaş, Cemal (2012), "Muhasebe Ve Vergi Denetiminde Muhasebe Hata Ve Hileleri’, Ekin Basın Yayın Dağıtımı.

Brown, R. Patrick, (1983). Independent Auditor Judgement in the Evaluation of Internal Audit Functions, Journal of Accounting Research, Volume:21, Number:2, Autumn, pp. 444- 456.

Carcello, V. Joseph, - Hermanson, R. Dana, - Raghunandan, Kannan. (2005). Factors Associated with U.S. Public Companies' İnvestment in İnternal Auditing, Accounting Horizons, Volume: 19 (2), pp. 69-84.

Carey, Peter - Craswell, Alison - Simnett, Roeger, (2000). Voluntary Demand for Internal and External Auditing by Family Businesses. Auditing: A Journal of Practice \& Theory, Volume: 19 (supplement), pp. 37-51.

Coenen, Tracy, (2008) Essentials Of Corperate Fraud, Ins.,Newyork, USA, John Willey\&Sons.

Çıtak, Fatma (2013), "Hileli Finansal Raporlamada İç Denetçilerin Sorumluluğunun Tespitine İlişkin Bir Araştırma", Niğde Üniversitesi, Sosyal Bilimler Enstitüsü, Yayınlanmamış Yüksek Lisans Tezi, Niğde, Türkiye. 
Doğan, Saime - Kayakıran, Dilek (2017), “İşletmelerde Hile Denetiminin Önemi”, Maliye Finansman Yazılar1, ss. 167-188

Doğan, Zeki - Çıtak, Fatma (2017), "Hileli Finansal Raporlamada İç Denetçilerin Sorumluluğunun Tespitine İlişskin Bir Araştırma" İşletme ve İktisat Çalışmaları Dergisi, Cilt: 15, Sayı: 2, ss. 49-62.

Doyle, T. Jeffery. - Ge, Weilli - McVay, Sarah. ( 2007). Accruals Quality and Internal Control Over Financial Reporting, The Accounting Review, Volume:82, Number: 5, pp. 1141-1170.

Dumanoğlu, Sezai (2005); "Hata ve Hile Ayrımı: "Hile Denetimi”, Marmara Üniversitesi İ.̇.B.F Dergisi, 20(1) ss. 347-358.

Durmuş, Cem Niyazi - Oktay Taş (2008), Denetim; SPK Düzenlemeleri ve 3568 Sayılı Mevzuat Kapsamında, İstanbul: Alfa Yayınları.

Güredin, Ersin (2010), Denetim ve Güvence Hizmetleri SMMM ve YMM'lere Yönelik İlkeler ve Teknikler, 11. Basım, İstanbul, Arıkan Basım Yayım.

Hacihasanoğlu, Tansel - Karaca, Nervan (2015), "Potansiyel Muhasebe Meslek Mensuplarının Hile Algısı Üzerine Bozok Üniversitesi'nde Yapılan Bir Araştırma”, Niğde Üniversitesi İktisadi ve İdari Bilimler Fakültesi Dergisi, Cilt:8, Sayı:1, ss. 117130

Karagöz, Yalçın (2014), "SPSS 21,1 Uygulamalı Biyoistatistik” 1. Bask1 Nobel Yayınevi, Ankara

Kiracı, Murat - Çelikay, Murat - Şengül, Duygu (2014), "İç Denetçilerin Hileler Karşısındaki Sorumluluğunun İç Denetim Mesleki Uygulama Çerçevesi Açısından Değerlendirilmesi”, Muhasebe Bilim Dünyası Dergisi, Cilt: 16, Say1: 2, ss. 307-325.

Küçük, Ergün - Uzay Saban (2009), "Hileli Finansal Raporlamanın Oluşumu ve Doğurduğu Sonuçlar”, Erciyes Üniversitesi İktisadi ve İdari Bilimler Fakültesi Dergisi, Say1:32, ss.239-258.

Küçük, Ergün (2009), "Hileli Finansal Raporlamanın Engellenmesinde Kurumsal Yönetim ve Dış Denetimin Rolü: Türkiye'deki Denetim Firmalarına Yönelik Bir Araştırma”, Erciyes Üniversitesi Sosyal Bilimler Enstitüsü, Yayınlanmamış Doktora Tezi.

Küçükkocaoğlu, Güray - Küçüksözen, Cemal (2004). "Finansal Bilgi Manipülasyonu: İMKB Şirketleri Üzerine Ampirik Bir Çalışma", 1st International Accounting Conference on the Way to Convergence, Kasım 2004, İstanbul, Muhasebe Bilim Dünyası (MÖDAV) Bildiri Kitab1.

Özeroğlu, Ali İhsan (2014) "Finansal Aldatmaca ve İşletme Hileleri” Akademik Sosyal Araştırma Dergisi, Cilt:2, Sayı:2, ss. 186-196.

Pehlivanlı, Davut (2010), Modern İç Denetim ve Genel İç Denetim Uygulamaları, Ankara, Beta Yayınevi. 
Pickett, K. H. Spencer, (2003), The Internal Auditing Handbook, John Wiley \& Sons,Ltd, USA.

Skousen, Christopher J. (2004), “ An Empirical Investigation Of The Relevance And Predictive Ability Of The SAS 99 Fraud Risk Factors" Doctor Of Philosophy, Oktahama State University, UMI Dissertion Services, USA.

Şengür, Evren Dilek (2010), "İşletmelerde Hile, Hilelerin Önlenmesi, Hileli Finansal Raporlama İlgili Düzenlemeler ve Bir Araştırma", Yayınlanmamış Doktora Tezi, İstanbul Üniversitesi Sosyal Bilimler Enstitüsü, İstanbul, Türkiye.

Tarhan Mengi, Banu (2013), "Hileli Finansal Raporlama” Beta Yayıncılık.

Tekin, Halil, (1987), “Eğitimde Ölçme ve Değerlendirme”, Ankara, Mesa Yayınları.

Tepeli, Yusuf - Kayıhan, Burak, (2016), "Muhasebe Manipülasyonunun BENEİSH Modeli İle Tespit Edilmesi: BİST Gıda Maddeler Sanayi Sektörü'nde Bir Uygulama” Yönetim ve Ekonomi Araştırmaları Dergisi, Cilt: 14 Sayı: 4, ss. 245-264.

TİDE, (2008), “Uluslararası İç Denetim Standartları Mesleki Uygulama Çerçevesi, Kırmızı Kitap, Türkiye İç Denetim Enstitüsü, No:4,Tide Yayınları.

Türedi, Hasan - Alıcı, Ümmü Gülsüm (2014), "Mali Raporlama Hilelerinin Tespit ve Önlenmesinde İç Kontrol Yapısının Önemi”, Finansal Araştırmalar ve Çalışmalar Dergisi, Cilt: 6 Say1: 11, ss. 110-933.

TÜSİAD. (2008). Kurumsal Risk Yönetimi, Yayın No. TÜSİAD-T/2008-02/452, , İstanbul, Graphis Matbaa Sanayi ve Ticaret Ltd. Şti.

Uçma, Tuğba (2010), "Finansal Bilgi Manipülasyonunda ve Hileli Finansal Raporlamada Denetçi Sorumluluğunun Belirlenmesine Yönelik Yapısal Eşitlik Modeli (SEM) Uygulaması", Yayınlanmamış Doktora Tezi. Dokuz Eylül Üniversitesi, Sosyal Bilimler Enstitüsü, İzmir, Türkiye.

Uçma, Tuğba (2011), "Hileli Finansal Raporlamada İç Denetçi ve Denetim Komitesi Sorumluluğunun Belirlenmesi: Bir Yapısal Eşitlik Modeli Uygulaması”, Muhasebe ve Vergi Uygulamaları Dergisi, Ankara Serbest Muhasebeci ve Mali Müşavirler Odası Yayınları, Cilt: 4, Sayı: 1, ss. 1-32.

Uyar, Süleyman (2009), “İç Kontrol ve İç Denetim, 5018 Sayılı Kanun Açısından, Ankara, Gazi Kitapevi.

Varıcı, İdris (2012), Hileli Finansal Raporlama Açısından Denetçinin Raporlarının İncelenmesi, Yayınlanmamış Doktora Tezi, Gümüşhane Üniversitesi, Sosyal Bilimler Enstitüsü, Gümüşhane, Türkiye.

Wallace, P. Eric, (2008): Construction Guide: Accounting and Knowledge Based Audits, Nashville TN, CCH.

Wolfe, T. David - Hermanson, R. Dana (2004), "The Fraud Diamond: Considesing The Faur Elements Of Fraud", The CPA Journal, December: pp. 38-41, http://www.3.uta.edu/faculty/subramaniam/CPAS2004.pdf. ( 26.09.2016). 
Yıldız, Ekrem - Başkan, Derya (2014), "Muhasebe Hilelerini Önlenmesinde Kullanılan Araçlar: BİST Şirketleri Üzerine Bir Araştırma", Muhasebe ve Finansman Dergisi, Nisan, Say1; 62, ss.139-159.

SPK, Sermaye Piyasası Kurulu, Sermaye Piyasasında Bağımsız Denetim Standartları Hakkında Tebliği (Seri: X, No: 22) .

Association Of Certified Fraud Examiners - ACFE, 2006-2008-2016 Report To The Nation Occupational Fraud\&Abuse - http://www.acfe.com/rttn-archive.aspx. (26.09.2016).

Vergi Usul Kanunu, www.mevzuat.gov.tr

SAS, Statement Of Auditing Standarts

http://www.aicpa.org/research/standards/audiattest/downloadabledocuments/au-c00240.pdf. (15.04.2018).

https://kemaldoymus.files.wordpress.com. (13.06.2018) 
